\title{
An Overview on Different Legal Systems and the Reflection in Kosovo
}

\author{
M. Sc. Samedin Mehmeti, PhD Cand. \\ European University of Tirana, Albania \\ samedinmehmeti@yahoo.com
}

\begin{abstract}
The state apparatus represents one of the fundamental elements of the development of contemporary society. While the right and law represents a basic understanding of the existence of the state power that performs in order to preserve a balance between the action which is accepted by society and other behaviors that by law are prohibited. The state actions principally are based on the rule of law, namely the legal system accepted or elected by people. Studying different legal systems, it shows that there are similarities more than the differences between them. Despite very different legal cultures, processing methods and institutions, different legal systems exhibit convergence in the treatment of different legal issues. As a result of these processes, many of the differences between common law and civil law now look more like nuances rather than as major differences. The differences are mostly pronounced in the styles of using legal argument, methodology, content and legal norms etc. Various legal systems, using different tools, aimed at the same purpose, and similar results are often taken from different justifications. Often it happens in practice that, despite the use of diverse tools and methods, they arrive at the same solutions or similar ones and it certainly that should not be surprising. So it can rightly be concluded that despite many changes, legal systems aim at achieving the same objective. While generally the target of the state is always and in any system the implementation of norms and rules set in advance, what the contemporary world tends to be considered as respect for the rule of law. In general, the objective of the state authorities in every system is the implementation of the norms and rules set in advance, that concept in the contemporary world tends to be considered as respect for the rule of law. Since Kosovo was part of the former Yugoslav federation and practically until the end of the war of 1999, in the absence of state sovereignty and subjectivity, people of Kosovo were not in a position to choose, like other sovereign nations which legal system will be applied on their lives. Without the will of the citizens, in Kosovo was applied a type of Continental legal system, with certain specific elements that were mostly common in other countries of former Eastern European Communist bloc. In the first years after liberation, until new legislation was passed through the legislative system, it was continued with the older system, through some minor changes. While at a later stage after the adoption of the new legislation, was introduced a large scale reform to the exciting system through the application of the combination of elements of Anglo-Saxon system, this reform which is to this day is in process as well.
\end{abstract}

Keywords: System, Legal, State, Sovereignty, Continental, Anglo-Saxon, Comunist

\section{Introduction}

State as such, represents one of the basic elements for the development of contemporary society. While the legal system, to a basic understanding of the existence, represents the apparatus that takes care to preserve the balance between the actions accepted and those behaviors that are prohibited by the legal norms set out by the society. Any operation or action should be based on the principles of the rule of law. If a society is faced with violation of the rule of law, in most of the cases people act individualistically and while some of the members of the society suffer this condition in the form of victims without any compensation, others in many cases may take the law enforcement in their hands or other forms of self-judgment.

The rule of law means a legal system that works regardless the functioning methodology of that system. In this case important is the existence of the legal system which provides direction on the basic rules that determine the functioning of society and legal system is helping to put them into practice.

Public confidence in the legal system is necessary for overall economic development, since it creates an environment where citizens feel secure. Banks and financial institutions can carry out their transactions, unpaid debts will be returned, people pay their taxes and obligations. And in return they will receive proper public services, improvements in infrastructure and so on. The legal system should also ensure development of: culture, media, educational system etc. With a dysfunctional legal system, in general, people feel insecure. The basic element for the creation of public confidence is the 
belief that the rules, laws and the whole normative spectrum, and other legal elements for what the legal system is exciting. As an agreement in a democratic society and should be implemented by the entire society and state structures.

A very important component of the legal system regardless of any judicial system, it is the transparency. A transparent legal system should be a tool to eliminate corrupt elements within the system. It should be noted that corruption is a phenomenon in which people are not necessarily voluntarily included. For this reason, it is very important for the legal system to protect its participants from the corruption of voluntary or involuntary involvement in corruption.

Review different legal systems show that there are more similarities than differences between legal systems, despite very different legal cultures, processing and institutions. Although different legal systems, exhibit convergence in the treatment of different legal issues. Under pressure from globalization contemporary legal systems show some signs of convergence. Many of the differences that exist between legal systems are much less visible because of the changes which have passed through these legal systems. Already it is clear that the role of the courts in addition to the implementation is more present in the creation of the law even this role is greatly increased.

As a result of these processes many of the differences between common law and civil law now look more like nuances rather than major differences. The differences that exist between the continental and the Anglo-Saxon law should not be exaggerated. It is also important to note that there are differences on many issues. The differences are mostly pronounced in the styles of argument, the methodology and the content of legal norms. Using various tools, aimed at the same purpose, and similar results are often taken from different justifications. Often it happens in practice that despite the use of different tools and methods, the result arrives at the same solution or similar and it certainly should not be surprising. So it can rightly be concluded that despite many changes the legal systems are more or less the same. While a certain rapprochement between the continental system and common law system is obvious and this trend is likely to continue, there are still important differences and they will continue to exist for an indefinite period. Recognition of these differences is necessary for any professional who deals with the legal matters.

Nevertheless, the differences in some areas are substantial in relation to the parties as well as procedures. Every legal system may have some advantages and some disadvantages. If a foreign legal system has several advantages, why we would not incorporate them into the domestic legal system? In this way, the resulting convergence of two legal systems can only contribute to the common purpose of which should be to create a fair system, convenient and accepted legal system that can provide legal certainty and protection for all citizens.

\section{CONTINENTAL LEGAL SYSTEM}

Continental legal system can also be described as a legal tradition which has its origins in the Roman law that was codified in "Justinian's Corpus Juris Civils" or as we know it from practice "The Justinian Code". This legal tradition was practiced and is developed during history mainly in the continental part of Europe ${ }^{1}$. Today, continental legal system or Romano-Germanic, is present in in all continents of the world. This system is based on concepts, categories and rules derived from Roman law, with some influence of the legal traditions, sometimes greatly supplemented or modified by local custom or culture. The tradition of civil rights, although secularized over the centuries and decided to focus more on individual freedom, promotes cooperation between human beings. ${ }^{2}$ This tradition itself, it could be divided further into impacts that have had Roman norms, rules influenced by French law and the Germanic family of legal norms, or dominated by German jurisprudence. In particular the Roman legal norms were modeled on the French Civil Code approved in 1804 otherwise known as "The Code Napoleon". Napoléon Bonaparte was the French very successful leader, who managed to straddle large parts of Europe. This invasion which had not only meaning in occupying territories, but also the classic invasion of ideas and culture. French Civil Code was also a short collection of clear legal principles based on common sense and experience and theory in the country. ${ }^{3}$

\footnotetext{
1 Ismajli O. 2011.

2 http://www1.law.Isu.edu/clo/civil-law-online/what-is-the-civil-law/

3 http://www.mu.ac.in/myweb_test/M.A.\%28Part\%20-1\%29\%20History\%20Paper\%20-\%20III\%20-

\%20History $\% 20$ of $\% 20$ Europe $\% 20 \% 281789-1919 \% 29 \% 20-\% 20 \% 28$ Eng $\% 29$.pdf 
The German Civil Code that was adopted in 1896 and entered into force since 1900, this code was also a consequence of movements and ideas from codified legal norms initiated by the French code ${ }^{1}$. This is typical for almost all countries of continental legal system or as is known in international legal practice "Civil Law System". The main characteristic of these norms is that the law is almost entirely codified, very much arranged and structured, broadly based in general principles, where not necessarily are determined the details.

The main element of the continental legal system lies in the fact that the right is written in laws or codes which are described as a guide, authoritative and systematic, with general coverage in legal life. Among the legal codes of different countries of the continental system, despite the fact that there are many common issues, there are still some important differences, and they are often grouped into those that address issues under the Roman tradition and the tradition of Germanic legal family. Although these legal codes of different countries are not homogeneous, there are certain characteristics of all legal codes which bind them together and determine what is practiced differently in every system.

Basically continental legislation is classified, structured and mainly contains a large number of rules and general principles, but often is described as legal norms with lack of detailed data's. One of the basic characteristics of continental legislation is that the main task of the court is to apply and interpret the legal norms written/included in the code. The assumption is that the code regulates all cases that may occur in practice, and when specific cases are not regulated by the code, the courts must apply general principles to fill the gaps.

After the end of World War II, Kosovo as an autonomous province within the former Yugoslav Federation, as well as other republics of the Federation, had a continental legal system. This system was applied not for the fact that this was the will of the people of Kosovo, neither because of any tradition. In fact people of Kosovo, were not even able to choose because this type of legal system was applied to all 6 Socialist Republics and 2 Autonomous Provinces in the ex-Yugoslav Federation. Mainly his system with some small changes was applied almost in most European countries of the former socialist bloc.

After the changes made in the Kosovar legislation especially after 2004, when it was approved the Interim criminal Code and the Code Criminal Procedure, we find changes that lead towards a combination of continental system with elements of Anglo-Saxon legal system². This tradition continued even further with the adoption of other normative legal acts and today Kosovo can be described as a functioning state based mainly in continental system of law, who apply techniques and methods of common law system such as judicial precedent ${ }^{3}$.

\section{ANGLO-SAXON LAGAL SYSTEM}

Anglo-Saxon legal system means the body of legal principles that prevailed England since the 6th century until the Norman Conquest in 1066. In light of the Scandinavian rules and the so-called barbarian laws (Leges barbarorum) of continental Europe, was constituted a body of rules called Germanic law. Anglo-Saxon law was written in the vernacular format and was relatively far from the Roman influence, which had great influence on mainland and laws from that period of time were mainly written in Latin language. Roman influence in Anglo-Saxon law was indirectly and exercised mainly through churches 4 .

Anglo-Saxon legal system or "Common Law" is a legal tradition, which in most cases was developed in England and is present today as well. This legal tradition is the basis of the law, not only for England, as the country of origin, but also for Wales, Ireland, almost all the states of USA (with the exception of Louisiana), most of Canada (except Quebec) and in most countries that have adopted this system. Here in the first place make part former British colonies which are generally independent members of the Association of Commonwealth states, but in large parts are connected to related rules and religious as well as local customs laws like India, Pakistan, Malaysia or Jamaica.

\footnotetext{
$1 \mathrm{http}: / /$ faculty.cua.edu/pennington/Law508/GermanLegalHistory.htm

2 Kodi i Perkohshem i Prodedures Penale, 2004

${ }^{3}$ Morina V. (2013)

4 http://global.britannica.com/EBchecked/topic/25121/Anglo-Saxon-law 
Principles of Anglo-Saxon legal system appear to most trials reported, usually given by the higher courts, in connection with specific situations arising from disputes, which the courts have already judged. In general all the common rules of the Anglo-Saxon legal system appears to be as specific procedures detailed in comparison with the rules and procedures of the continental legal system. The most obvious difference between this system and the continental system is that the continental system is a codified system, while the Anglo-Saxon legal system is not created entirely through written legislation, but rather is based on judicial jurisprudence.

One of the fundamental principles of this system is that judicial decisions, which are often taken by the higher courts, issued on a similar case, followed in subsequent cases, ie. That case law precedent must be respected. This principle is known as "staredecisis" (namely the principle of the court is based on the principles set by decisions in previous similar cases from another higher court) and has never been legalized, but is considered as binding by the courts, which can be modified.

The claim that Anglo-Saxon legal system is created based on written law, but separate in cases adjudicated or judicial precedent is only partially true, as the continental legal system is based in large part on codes, laws, statutes that judges are obliged to apply and interpreted in approximately the same way act judge in the Anglo-Saxon legal system.

\section{MIXEC OR "HYBRID" LEGAL SYSTEM}

In addition to the mentioned systems, which in reality is difficult to find a pure but in most cases there are different combinations and mixed legal systems or "Hybrid", which cannot be tied so completely clear or have elements of AngloSaxon legal system and even the continental legal system and therefore it is so called hybrid legal systems. The term "mixed", which we have chosen over other terms such as "hybrid", "mixed" or "composed" should not be interpreted restrictively. This category includes cases of countries where two or more systems apply cumulatively or interactively, but also when there is a confrontation of systems, as a result of the field more or less clearly defined application. ${ }^{1}$ In those legal systems, the right to force stems from more than one of these legal traditions, for example, in Scotland or Quebec, where the traditions of the law are common.

\section{THE LEGAL SYSTEM OF FORMER COMUNUNIST COUNTRIES}

Another group set up somewhere so special that can be discerned, in any case until around 1990, was the legal system of the countries with communist or socialist legal systems. Even after the collapse of the political system almost completely and the implementation of another system or market economy and democracy in most of these countries, it is still useful to treat. This is because many of the similarities in the system, characteristic of these countries can only be understood as the result of 50 years of communist rule. This, especially if one wants that, at all events, to distinguish specific subgroups within the continental legal system which is used with certain changes in most of these countries.

Within the former communist states were more or less three subgroups that can be distinguished:

- Soviet law, also called socialist law, took place mainly in Russia after the arrival of the communists in power in 1917. This system was imposed in all parts of the Soviet Union in $1920 .{ }^{2}$ In Russia and other countries of the former Soviet Union, provisions are almost identical in content and generally were applied in succession law and international private law in these sometimes still used or issued other but based on provisions dating from this time.

- $\quad$ Other countries of Eastern Europe (including the Baltic States) had differed legal system from other communist countries, in particular from countries of former Soviet Union, especially in terms of international private law. Generally this is seen as a result of the permanent tendency towards greater freedom, for example of the legal agreement and marital or succession law. After the fall of the communist system and release from tutelage of the former Soviet Union, the reform of the legal system in most of these countries returned to their laws from the time of before the Second World War.

- The third subgroup consists of countries of East, South East Asian countries. In particular, here comes the People's Republic of China, which has always exposed

\footnotetext{
1 http://www.juriglobe.ca/eng/sys-juri/class-poli/sys-mixtes.php

2 http://global.britannica.com/EBchecked/topic/557116/Soviet-law
} 
considerable differences in the legislation of the Soviet Union countries. But some differences in the legal system were to be seen also in the countries like Mongolia or Vietnam. These countries followed the so-called Soviet model closely. A more typical system that represents a special case in terms of the legal system is Cuba. This is the only Latin American country who is still in the legal system that can be called communist. The legal system of this country, especially in terms civil relations with bigotry still maintains continuity or is very close to the previous system of the former Soviet Union, while in terms of private international law is a legal tradition influenced by Latin American countries.

\section{DIFFERENCE AND COMMON ELEMENTS THAT CHARACTERIZE THE MAIN SYSTEMS OF LAW}

If we want to make comparisons and examinations more closely, character or details that permeate existing main legal systems, then it also becomes clear that they have their uniqueness but also the similarities. To find certain distinguishing characteristics between the Anglo-Saxon legal system and Continental legal system, accordingly assigned to the application in different countries of course differ from one another in both time as well as in space. In this case we will only examine some distinctive features, which in fact do different and distinguish these systems from each other.

\section{SOURCES OF LAW}

Continental system bases the law as the main source of legislation, judicial system is typically inquiry, unlimited by precedent, and composed of judicial officials. The rule of law is to build a bridge to the available collection and writing of laws relating to all citizens and that judges should follow that practice ${ }^{1}$. One of the most important and widely known is undoubtedly distinguishing different sources of law in which support is these legal systems. It cannot be taken as just perfect widespread view that these two systems differ from each other by the fact that the Anglo-Saxon legal system is based on the judge that creates cases the only source of the right, while the in the Continental legal system the right is the source. It is a law adopted as the only source of that right. Freely can be found with such absolutism this distinction has never been correct or not correct. On the one hand the law is not codified as such exists only in the Anglo-Saxon legal system, but no matter what form it is presented is still a certain importance. Even for some issue certain legal solutions are offered traditionally in constitutive format. Countries that apply the Anglo-Saxon legal system in most of the cases have codified laws. Which is stem from a long legislative process that means they are approved by parliament and the courts must take into account in their decisions even in cases where existing precedents apply court.

As another feature distinguishing element between legal systems, is the principle of the application of "judicial precedent" that could be considered as a work methodology that is used in Anglo-Saxon legal system. Analyzing court decisions on cases that have similarities, to find a general solution or that is used more and that has given better results. Solution used in most of these cases then be used in the actual dispute resolution. When we refer to judicial precedent we are alluding to what is known as judicial practice or a law created by judges. ${ }^{2}$ While the judges in the continental legal system may be obliged to apply the laws or codes written, judges apply the Anglo-Saxon legal system doctrine called "stare decisis" which is a legal principle that dictates that courts can not violate the precedent that applies to first degree. This is a general principle that when a matter is settled by judicial decision, it sets a precedent that is later to be respected. ${ }^{3} \mathrm{~A}$ court decision is a precedent if that decision will be applied in future cases. But, for such application, the court's decision should contain a guide, to achieve by the use of reason rationally and that this reasoning can be found by other courts. A judicial precedent is binding until the moment is broken by the decision of a higher court or declared invalid by the approval of any legal act. The high court also may review and revoke its previous decision.

\footnotetext{
1 http://www.lawteacher.net/free-law-essays/constitutional-law/contrast-between-common-and-continental-legal-systems-constitutionallaw-essay.php

2 http://www.ukessays.com/essays/law/judicial-precedent-and-doctrine-of-stare-decisis-law-essay.php

3 http://legal-dictionary.thefreedictionary.com/stare+decisis
} 


\section{REFERENCES}

[1] Encycopedia Britanica-Anglosaxson Law, accessed 03/03/ 2015

[2] Encycopedia Britanica-Soviet Law, accessed 13/03/ 2015

[3] Free Dictionary - Stare Decisis, accessed 19/02/ 2015

[4] German Legal history, accessed 11/02/ 2015 http://faculty.cua.edu/pennington/Law508/GermanLegalHistory.htm

[5] History of Europe- "French Revolution", accessed 10/02/ 2015

[6] http://global.britannica.com/EBchecked/topic/25121/Anglo-Saxon-law

[7] http://global.britannica.com/EBchecked/topic/557116/Soviet-law

[8] http://legal-dictionary.thefreedictionary.com/stare+decisis

[9] http://www.lawteacher.net/free-law-essays/constitutional-law/contrast-between-common-and-continental-legalsystems-constitutional-law-essay.php

[10] http://www.mu.ac.in/myweb_test/M.A.\%28Part\%20-1\%29\%20History\%20Paper\%20-\%20111\%20\%20History\%20of\%20Europe $\% 20 \% 281789-1919 \% 29 \% 20-\% 20 \% 28$ Eng $\% 29$.pdf

[11] http://www1.law.Isu.edu/clo/civil-law-online/what-is-the-civil-law/

[12] Ismajli O. (2011), "Fillet e se drejtes", Universiteti i Prishtine, Kosove.

[13] Kodi i përkohshëm i procedurës penale, Kuvendi i Kosovës, Prishtine, 2004.

[14] Law Teacher- "Continental Legal System", accessed 23/02/ 2015

[15] LSU-Law centre - "What is the Civil Law", accessed 10/02/ 2015

[16] Morina V, (2013) -"Aktgjykimet dhe vendimet e Gjykatës Kushtetuese të Kosovës - roli i precedentit dhe fushëveprimi i nenit 116.1 të Kushtetutës së Kosovës", botuar ne Revisten shkencore "E drjta" numer 1/2013. Prishtine.

[17] UKESSAYS- "Judicial Precedent And Doctrine Of Stare Decisis Law Essay", accessed 09/03/ 2015 http://www.ukessays.com/essays/law/judicial-precedent-and-doctrine-of-stare-decisis-law-essay.php

[18] University of Otava- "Mixed legal systems", accessed 05/02/ 2015 http://www.juriglobe.ca/eng/sys-juri/classpoli/sys-mixtes.php 